\title{
Egenmåling av intraokulært trykk
}

\author{
Et tonometer for egenmåling av intraokulært trykk kan være et godt hjelpemiddel hjemme for enkelte \\ pasienter med glaukom, men det kan også være problematisk.
}

Publisert først på nett 29.3. 2012 Engelsk oversettelse på www.tidsskriftet.no

Mange pasienter med diabetes foretar egne målinger av blodsukker. Dette kan være positivt for egen sykdomsforståelse og gi bedre pasientoppfølging. Også glaukom innebærer livslang oppfølging, der pasienten må møte hos øyelege for måling av intraokulært trykk, vanligvis flere ganger per år. Det finnes ulike tonometre som kan egne seg for egenmåling i hjemmet, og det skjer gradvis en utvikling mot mer presise og brukervennlige instrumenter (1).

Et nytt og portabelt apparat som kan måle øyetrykk uten bruk av lokalbedøvende dråper, er nå i salg i Norge (2). Produsenten er finsk, og tonometeret veier bare 150 gram. Trykket måles ved at en tynn og magnetisert målepinne, beregnet for engangsbruk, treffer hornhinnen i et kort øyeblikk (fig 1). Instrumentet registrerer så hvor raskt og med hvor stor kraft målepinnen returnerer etter å ha truffet hornhinnen. Dersom øyetrykket er høyt, vil målepinnen komme raskere tilbake og med større kraft enn ved lavt trykk. Resultatet angis på en intervallskala. Alle målinger lagres på apparatet og kan overføres til en datamaskin, slik at nøyaktige verdier og tidspunktene for målingene kan avleses.

En tysk studie har vist at dette tonometeret er ganske nøyaktig sammenliknet med applanasjonstonometre (3). Øyeleger bruker i dag hovedsakelig applanasjonstonometre, som estimerer trykket ved å måle hvor stor kraft som må brukes for å presse flatt et bestemt areal av hornhinnen.

\section{Intraokulært trykk og glaukom}

Høyt intraokulært trykk er den største risikofaktoren for utvikling og progrediering av glaukom med tap av synsfunksjon til følge. Senkning av øyetrykket er den eneste behandlingen som finnes. Dette kan oppnås ved hjelp av medikamenter, laserbehandling eller kirurgi. Dårlig etterlevelse ved behandling med øyedråper er vanlig.

De fleste øyefriske personer har et øyetrykk i området 10-21 mm Hg. Risikoen for å utvikle glaukom øker med økende trykk, men det finnes pasienter med glaukom uten forhøyet trykk (såkalt lavtrykks- eller normaltrykksglaukom) og personer med høyt trykk uten glaukomskade (okulær hypertensjon). Trykket hos en enkelt person kan variere i løpet av døgnet (4).

Pasienter med trangvinkelglaukom kan ha nytte av egenmålinger. Slike pasienter kan få trykkstigning i mørke fordi kammervinkelen okkluderes når pupillen utvides. Pasientene kan da på en enkel måte måle trykket når de får symptomer. Mange av disse pasientene er relativt unge.

Noen åpenvinklede glaukomtyper, blant annet pigmentglaukom og pseudoeksfoliasjonsglaukom, kan være særlig egnet for egenmålinger fordi det intraokulære trykket er svingende. Pasienter med sekundært glaukom på grunn av uveitt eller neovaskularisering kan også få plutselig trykkstigning med eller uten symptomer. De fleste pasientene med åpenvinklet glaukom er imidlertid eldre og har et nokså stabilt intraokulært trykk, som derfor egner seg mindre for egenmåling. Noen ganger kan slike pasienter ha forverring av synsskaden til tross for akseptable trykkmålingsverdier på øyelegekontoret. Måling av trykket i hjemmet kan da avsløre trykktopper og motvirke dårlig etterlevelse.

Det finnes mange ulike trykksenkende øyedråper på markedet, og det kan være vanskelig å finne frem til de dråpene som har best effekt hos den enkelte pasient. Hjemmemålinger kan være nyttig for å finne den optimale kombinasjonen av øyedråper.

\section{Etiske og faglige overveielser}

Å oppnå korrekte måleverdier krever riktig bruk av tonometeret. God instruksjon og individuell tilpasning av apparatet forste gang er derfor viktig. Personer med dårlig syn og med nedsatt finmotorikk i hender kan ha problemer med å bruke instrumentet.

Egenmåling av intraokulært trykk har stor appell hos noen pasienter, og enkelte har kjøpt tonometer på eget initiativ. Mange glaukompasienter har imidlertid liten nytte av egenmålinger. Hyppige egenmålinger kan redusere livskvaliteten for mange pasienter, og målinger av tilfeldig høyt trykk kan skape angst og unødvendige legekonsultasjoner. Fravær av høyt trykk gir heller ingen garanti for at sykdommen ikke forverres. For å undersøke om det foreligger progrediering må uansett papiller vurderes og synsfeltprøve tas og tolkes av øyelege. Derfor bør man bare bruke tonometeret i samarbeid med lege.

\section{Konklusjon}

For noen pasienter med glaukom kan egenmålinger av intraokulært trykk være et godt supplement til øyelegekonsultasjoner. Egenmålinger kan øke intervallene mellom øyelegebesøk og fange opp personer som får uventet høyt trykk, slik at behandling

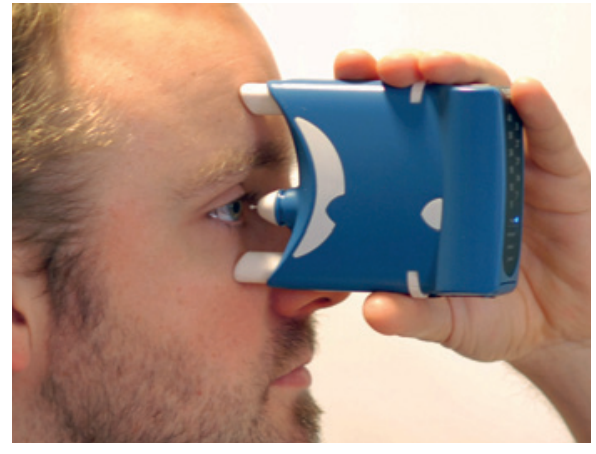

Figur 1 Tonometer for egenmåling i bruk. Foto Geir Qvale

kan intensiveres for å hindre at skaden progredierer. Monitorering av behandlingseffekt kan også utføres. Hjemmemåling kan i noen tilfeller brukes til hjelp ved diagnostisering av glaukom.

\section{Jon Klokk Slettedal \\ jon.klokk.slettedal@gmail.com \\ Bjørn Nicolaissen \\ $\emptyset$ yeavdelingen \\ Oslo universitetssykehus, Ullevål \\ og \\ Institutt for klinisk medisin \\ Universitetet i Oslo}

Jon Klokk Slettedal (f. 1973) er overlege og glaukomkirurg ved Oslo universitetssykehus og førsteamanuensis ved Universitetet i Oslo. Forfatteren har fylt ut ICMJE-skjemaet og oppgir ingen interessekonflikter.

Bjørn Nicolaissen (f. 1947) er overlege ved Oslo universitetssykehus og professor ved Universitetet i Oslo.

Forfatteren har fylt ut ICMJE-skjemaet og oppgir ingen interessekonflikter.

Litteratur

1. Liang SY, Lee GA, Shields D. Self-tonometry in glaucoma management-past, present and future. Surv Ophthalmol 2009; 54: 450-62.

2. iCare One tonometer: www.icaretonometer.com/ index.php?page=one (19.3.2012).

3. Rosentreter A, Jablonski KS, Mellein AC et al. A new rebound tonometer for home monitoring of intraocular pressure. Graefes Arch Clin Exp Ophthalmol 2011; 249: 1713-9

4. Bagga H, Liu JH, Weinreb RN. Intraocular pres sure measurements throughout the $24 \mathrm{~h}$. Curr Opin Ophthalmol 2009; 20: 79-83. 